\title{
Integrated Geochemical Investigations on Fe-Mn Nodules, Polymetallic Sulfides and Fe-Mn Oxides Recovered from Marine Sediments of Carlsberg Ridge, Northwest Indian Ocean
}

\author{
Samuel Olatunde Popoola* and Akinnigbagbe Edward Akintoye \\ ${ }^{1}$ Department of Physical and Chemical Oceanography, Nigerian Institute for Oceanography and Marine \\ Research, Nigeria \\ ${ }^{2}$ Department of Marine Geology and Geophysics, Nigerian Institute for Oceanography and Marine \\ Research, Nigeria
}

\begin{abstract}
The research and exploration of submarine minerals have increased exponentially due to the requirement for rare and critical metals (cobalt, silver, platinum) as additional supplements to the gradually depleting terrestrial metal source. Manganese nodules, Fe-Mn oxides and polymetallic sulfides represent the most important source of these aforementioned critical metals. This paper highlight the results of the integrated studies on recovered minerals grains (e.g., Fe-Mn nodules, Fe-Mn oxide crusts and polymetallic sulfides) from marine sediments of the Carlsberg Ridge (CR), Northwest Indian Ocean. Geochemical and mineralogical techniques (e.g., X-Ray Diffraction studies (XRD); Standard Emission Microscope equipped with Energy Dispersive Spectrometer (SEM-EDS) and Electron Probe Micro-Analysis (EPMA) were used in conjunction with binocular and stereographic microscopes on the separated mineral grains. The representative marine nodules from the sediment core collected at $\sim 300 \mathrm{~km}$ to the ridge segment are dark and botryoidal to spherical with average $\mathrm{Cu}, \mathrm{Co}, \mathrm{Ni}$ and $\mathrm{Zn}$ concentrations of $0.17 \mathrm{wt} \%, 0.19 \mathrm{wt} \%, 0.22 \mathrm{wt} \%$, and $0.15 \mathrm{wt} \%$. The sulfides of the near-vent sediments of CR showed euhedral texture, with average $\mathrm{Cu}$ and Co concentrations of up to 0.08 wt\% and $0.05 \mathrm{wt} \%$. The Fe-Mn oxide crust was yellowish to reddish-brown, poorly crystallized, with goethite minerals. The average $\mathrm{Ni}$ and $\mathrm{Cu}$ concentrations are $0.04 \mathrm{wt} \%$ and $0.60 \mathrm{wt} \%$. These studies further highlight the need to integrate all specializations and expertise for a thorough understanding of the growth, trophic interactions and resilience of the marine ecosystems in the Carlsberg Ridge and other vent fields in the Indian Ocean.
\end{abstract}

Keywords

Submarine minerals, Near-vent sediments, Carlsberg Ridge, Indian Ocean, Marine ecosystems

\section{Introduction}

The oceans cover more than $70 \%$ of the planet and represent a potentially promising new frontier for the research and exploration of minerals. The research and exploration of submarine minerals have greatly increased due to the requirement for critical metals and the recent drive for a green economy. Fe-Mn nodules, polymetallic sulfide minerals, and Fe-Mn crusts have been identified as the source of these critical metals such as Rare Earth Elements (REEs), Silver (Ag), Gold $(\mathrm{Au})$, Zinc $(\mathrm{Zn})$, antimony (Sb), Selenium (Se), Cobalt (Co), Tellurium (Te), Neodymium (Nd), copper (Cu), Manganese $(\mathrm{Mn})$, platinum $(\mathrm{Pt})$ and others [1].

Two typical micronodules have been identified in mid Ocean ridges and environments including the diagenetic micronodules and the micronodules that are precipitated from plume fallout of oxyhydroxide matter. Whereas, with distance away from the Mid Ocean ridge segments, hydrogenous and diagenetic processes dominate due to masked hydrothermal

*Corresponding author: Samuel Olatunde Popoola, Department of Physical and Chemical Oceanography, Nigerian Institute for Oceanography and Marine Research, PMB, 1279, Victoria Island, Lagos, Nigeria

Accepted: May 04, 2021

Published online: May 06, 2021

Citation: Popoola SO, Akintoye AE (2021) Integrated Geochemical Investigations on Fe-Mn Nodules, Polymetallic Sulfides and Fe-Mn Oxides Recovered from Marine Sediments of Carlsberg Ridge, Northwest Indian Ocean. Adv Environ Stud 5(1):394-403 
Citation: Popoola SO, Akintoye AE (2021) Integrated Geochemical Investigations on Fe-Mn Nodules, Polymetallic Sulfides and Fe-Mn Oxides Recovered from Marine Sediments of Carlsberg Ridge, Northwest Indian Ocean. Adv Environ Stud 5(1):394-403

signatures [2]. It is noteworthy that these micronodules are not easily observed as pure end members [2-5].

Polymetallic sulfides are one of the manifestations of hydrothermal activities with other diverse mineral assemblages such as pyrite/marcasite, chalcopyrite, bornite, covellite, digenite, isocubanite, pyrrhotite, barite, anhydrite, amorphous silica and Fe-oxide and hydroxides [6]. Ferromanganese oxides and crusts are widespread on the ocean floor and are formed through the precipitation of suspended iron and manganese oxyhydroxides owing to the hydrothermal-hydrogenetic supply. However, the hydrogenetic supply tends to affect the proportions of goethite $(\mathrm{FeOOH})$, vernadite, the $\mathrm{Mn} /$ Fe ratio, cerium anomaly $\left(\mathrm{Ce}^{*}\right)$, and the REEs, $\mathrm{Cu}$ and $\mathrm{Co}$ concentrations therein. These diverse marine mineral deposits (Fe-Mn nodules, polymetallic sulfides and Fe-Mn crust) are supplied to the marine sediments by slumping or fall-out of nearby buoyant plume $[2,7,8]$, therefore sediments can act as a sink to the three aforementioned mineral deposits.

Oceanographic factors such as global contouritic bottom-currents or upwelling undercurrents and plate tectonics have a great influence on the formation of these mineral resources in submarine environments like abyssal plains, seamounts and continental margins [1]. The essential techniques on the aforementioned oceanographic factors include a wide range of methodologies, such as multi beam bathymetry, remote-operated vehicles (ROVs), autonomous underwater vehicles (AUVs), magnetometers [1], and detailed micro and nano-scale mineralogical and geochemical in-situ investigations of marine mineral grains recovered from rocks and sediments.

This paper aims to integrate the results of micro-scale mineralogical and geochemical in-situ investigations of min- eral grains (e.g., Fe-Mn oxides, polymetallic sulphides) with the Fe-Mn nodules recovered from sediment core approximately $500 \mathrm{~km}$ East to Tianxu Hydrothermal field (THF) and $1100 \mathrm{~km}$ North-East to Wocan Hydrothermal field (WHF), Carlsberg Ridge (CR), Northwest Indian Ocean (Figure 1).

\section{Geological settings of Carlsberg Ridge (North- west Indian Ocean)}

The Carlsberg Ridge (C.R, Figure 2) is part of the Indian Ocean Ridge Systems (IORS) which is a long chain of active submarine volcanoes [9-13]. It defines the divergent plate boundary between the Indian and Somalian plates, which opened during the late Paleocene ( $55 \mathrm{Ma}$ ) when the Seychelles bank separated from the Indian plate [12,13-18]. The spreading rate along the Carlsberg Ridge gradually increases from North to South: with a half-spreading rate of $~ 11-16$ $\mathrm{mm} / \mathrm{yr}[11,18-20]$.

Previous research had been conducted on the geophysical investigations involving, the multi-beam swath bathymetry maps along with a few segments of the Carlsberg Ridge. Few of the previous reports on the morphological characteristics of the Carlsberg Ridge showed rugged topography and steep inner valley walls, similar to the ridge morphology of northern Mid Atlantic Ridge, and other slow-spreading ridges $[11,12,21,22]$. Three distinctive segment morphotypes have been identified in the C.R: 1) Symmetric segments with a shallow axial valley and smooth axial plateau; 2) symmetric segments with steep axial valley walls and a hummocky axial volcanic ridge (AVR), and 3) segments with deep axial valley walls, often with an asymmetric flank massif [23]. Subsequent exploration and scientific studies have led to the discovery of three active hydrothermal fields (i.e. mafic hosted Wocan-1

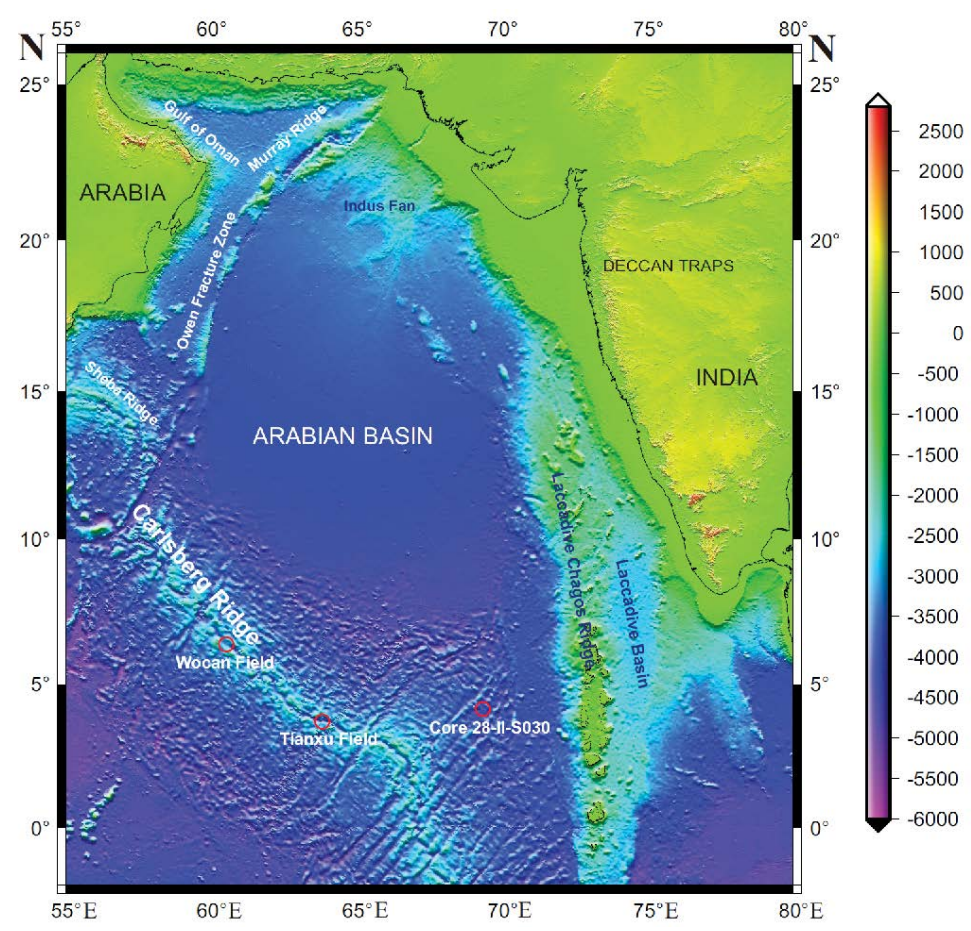

Figure 1: Bathymetric map of subsurface core samples where Fe-Mn nodules were isolated off Tianxiu and Wocan field. 


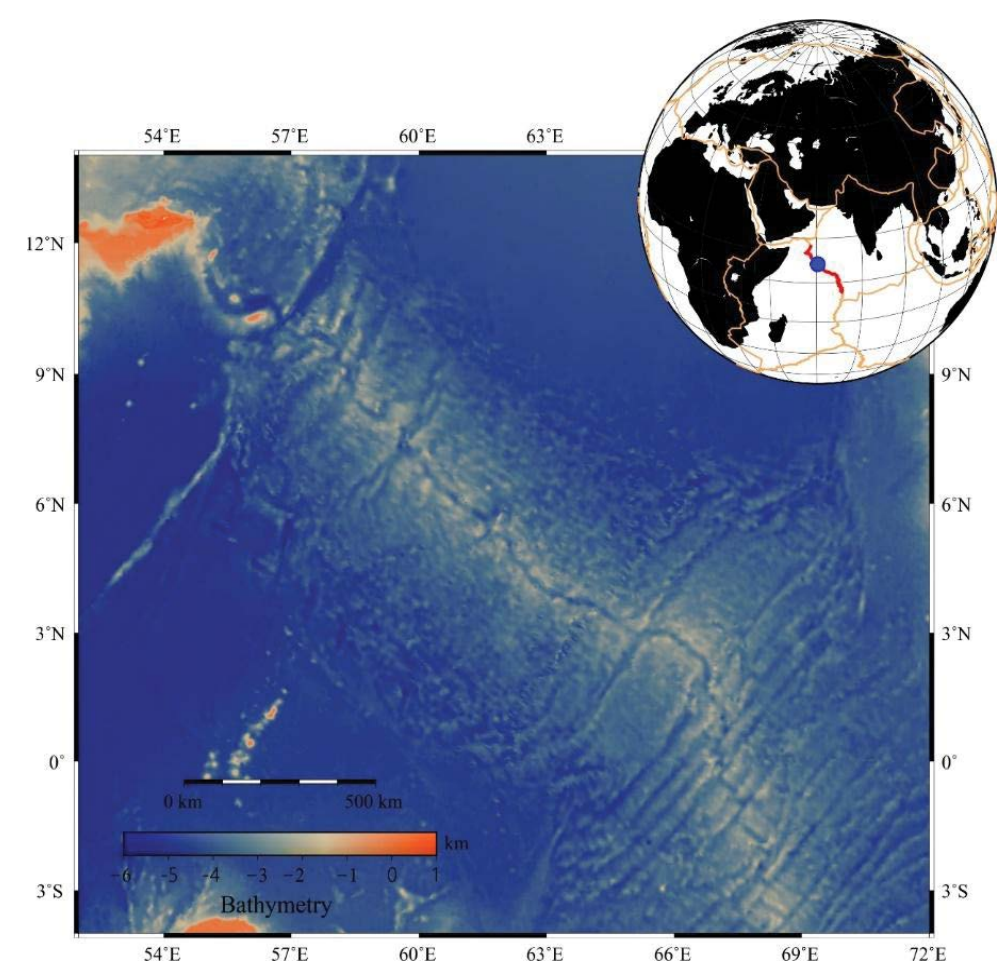

Figure 2: Bathymetric map of Carlsberg Ridge.

Table 1: Coordinates of sampling stations and type of sediment samples collected from the Northwest Indian Ocean.

\begin{tabular}{|l|l|l|l|l|l|}
\hline Site & Station & Longitude (E) & Latitude (N) & Depth (m) & Type of samples \\
\hline Wocan-1 & 28 -TVG07 & $60^{\circ} 31.534^{\prime}$ & $6^{\circ} 21.796^{\prime}$ & 2989 & Metalliferous sediment \\
\hline & 28 I-TVG08 & $60^{\circ} 31.635^{\prime}$ & $6^{\circ} 21.756^{\prime}$ & 2973 & Metalliferous sediment \\
\hline Wocan-2 & 28 I-TVG10 & $60^{\circ} 30.372^{\prime}$ & $6^{\circ} 21.866^{\prime}$ & 3104 & Metalliferous sediment \\
\hline & $28 I$ I-TVG05 & $60^{\circ} 30.226^{\prime}$ & $6^{\circ} 22.534^{\prime}$ & 3105 & Metalliferous sediments \\
\hline Ridge flank & 28 I-TVG13 & $60^{\circ} 13.190^{\prime}$ & $6^{\circ} 35.675^{\prime}$ & 3254 & Pelagic sediment \\
\hline & 28 I-TVG12 & $60^{\circ} 13.550^{\prime}$ & $6^{\circ} 30.462^{\prime}$ & 2009 & Pelagic sediment \\
\hline Core sediments & 28 II-TVMC01-S030 & $69^{\circ} 20.201^{\prime}$ & $4^{\circ} 07.52^{\prime}$ & 4228 & Pelagic sediment \\
\hline
\end{tabular}

(Figure 1) and ultramafic hosted Tianxiu (Figure 1), and Daxi hydrothermal field on the Non-transform offset along the Carlsberg Ridge [5,6,24-31].

\section{Methodology and Approach}

\section{Polymetallic sulfides and Fe-Mn oxides}

Bulk representative samples of marine sediments from 6 stations in Carlsberg Ridge (Table 1) were washed with ultra-pure water to remove interstitial salts and dried at $60^{\circ} \mathrm{C}$. Approximately $60 \mathrm{~g}$ of the sub-samples were wet-sieved to separate into $>63 \mu \mathrm{m}$ (sand size fraction) and $<63 \mu \mathrm{m}$ (silt and clay size). Polymetallic sulfide mineral grains and Fe-Mn oxyhydroxides and crust in the $>63 \mu \mathrm{m}$ fractions were examined, and hand-picked under the stereographic microscope, binocular microscope and standard Electron Microscope (SEM) equipped with an EDX analytical X-Ray system operated at an accelerating voltage of 20-30 kV. The isolated mineral grains were ultrasonically cleaned in ultra-pure alcohol to remove any seawater influence, then impregnated with epoxy resin and hardener (ratio 2:1), [5,6,26]. Representative grains from the minerals were analyzed using an Electron probe microanalyses (EPMA, JEOL JXA-8100) with an acceleration voltage of $24 \mathrm{kV}$, beam current of $1 \mathrm{nA}$ and a beam diameter of $5 \mu \mathrm{m}$ at the State Key Laboratory of Submarine Geosciences (KLSG), Hangzhou China. The analytical precision and minimum detection limits (MDL) are $>0.1 \mathrm{wt}$. $\%$ and better than $\pm 10 \%$.

\section{Fe-Mn nodules}

The selected working half of the subsurface sediment core collected at about $300 \mathrm{~km}$ from the Ridge Segment (Figure 3) was sliced into $4 \mathrm{~cm}$ interval. Fe and Mn concentrations were analysed from one-half of the core sediment samples by inductively coupled Plasma Mass Spectrometer (ICPMS) using Agilent 7700 ICPMS, and method ME-MS61 at the Australian Laboratory Services (ALS) Chemex Guangzhou Limited Company, China.

About $5 \mathrm{~g}$ of representative samples at $4 \mathrm{~cm}$ interval (e.g., $2 \mathrm{~cm}, 6 \mathrm{~cm}, 10 \mathrm{~cm} \ldots . . .38 \mathrm{~cm}, 42 \mathrm{~cm}$ ) were soaked in de-ionized water for 24 hours, and wet-sieved to separate $>63 \mu \mathrm{m}$ (sand size) fractions. Micro nodules were observed, and further 
Citation: Popoola SO, Akintoye AE (2021) Integrated Geochemical Investigations on Fe-Mn Nodules, Polymetallic Sulfides and Fe-Mn Oxides Recovered from Marine Sediments of Carlsberg Ridge, Northwest Indian Ocean. Adv Environ Stud 5(1):394-403

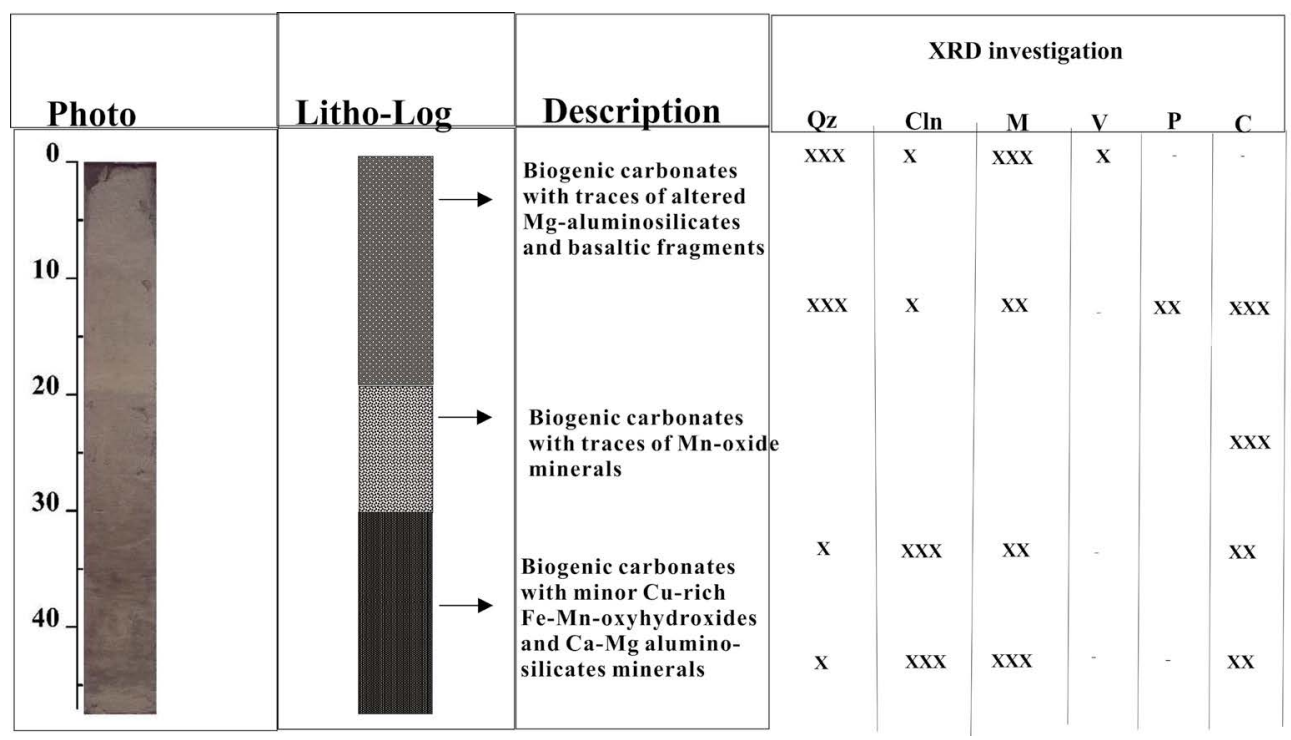

Figure 3: Photograph and mineralogical description of sediment core retrieved off Tianxiu and Wocan field XXX: Abundant, XX: Minor, $\mathrm{X}$ : Trace.

Abbreviations: Qz: Quartz, Cln: Clinochlore, M: Muscovite, V: Vermiculite, P: Phlogopite; C: Calcite.
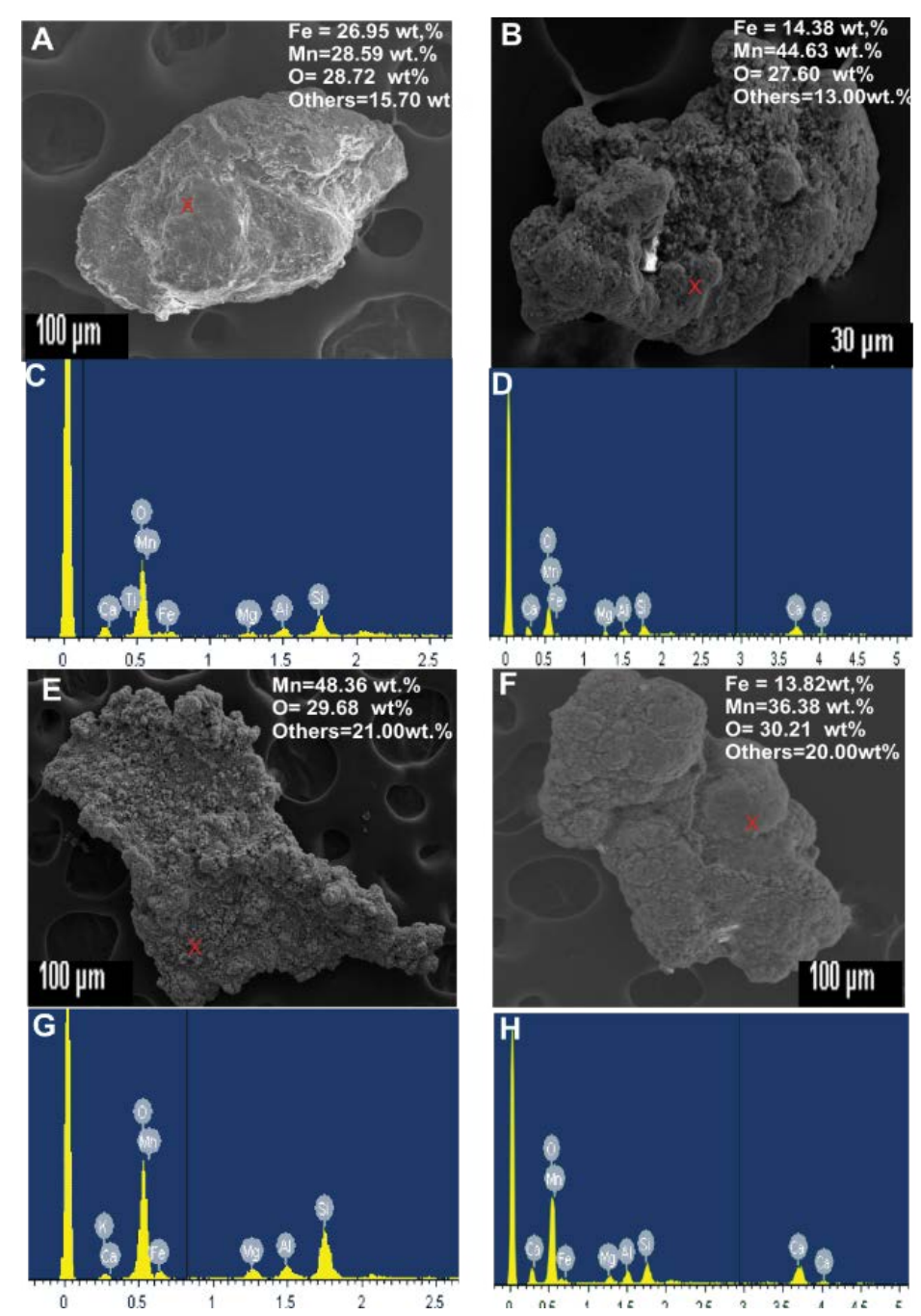

Figure 4: SEM morphology and EDS spectra of representative Fe-Mn nodules from the Carlsberg Ridge, NW Indian Ocean. The X indicate the analyse spot. 
hand-picked, temporarily at the third layer (unit III, 30-42.5 $\mathrm{cm})$. The grains were mounted on stud attached with carbon tapes from the sand-size sediment fractions using a binocular and stereographic microscope. X-ray diffraction studies (XRD) was conducted on the $<63 \mu \mathrm{m}$ (silt + clay size) fractions. The SEM-EDX, EPMA and Xrd investigations were operated at an accelerating voltage similar to the approach adopted on the sulfides and Fe-Mn crust at the State Key Laboratory of Submarine Geosciences (KLSG), Hangzhou China.

\section{Results}

\section{Geochemical and mineralogical investigations of isolated Fe-Mn micro nodules}

Based on the microscopic studies, the sediment core was divided into three units. The combinations of optical and SEM investigations on the isolated mineral grains revealed that unit I $(0-19 \mathrm{~cm})$ are majorly biogenic with minimal siliceous carbonates, traces of altered magnesium alumina silicates minerals, and altered basaltic fragments. Unit II $(20-29 \mathrm{~cm})$ are majorly biogenic with minimal siliceous carbonates and traces of Mn oxide minerals. Unit III (30-42.5 cm) majorly contains a mixture of biogenic carbonates, minor Cu-rich-Fe-Mn oxides, Fe-oxyhydroxides and calcium magnesium alumina silicates minerals (Figure 3).
The XRD investigations of the core sediments reveal quartz, clinochlore, muscovite, vermiculite, phlogopite and calcite (Figure 3). The micronodules were abundant in Unit III. The microscopic observation of representative marine nodules from the sediment core revealed dark brown and black coloured nodule. The micro-nodules ranges from botryoidal to spherical in shape and the SEM-EDS investigation showed $\mathrm{Mn}$ concentration of up to $44.63 \mathrm{wt} \%$, with Fe values of up to $26.95 \mathrm{wt} \%$ (Figure 4). The (EPMA) further revealed average $\mathrm{Cu}, \mathrm{Co}, \mathrm{Ni}, \mathrm{Zn}$ concentrations of $0.17 \mathrm{wt} \%, 0.19 \mathrm{wt} \%, 0.23$ $w t \%$, and 0.15 wt\% respectively (Table 2 ).

The enriched major elements $\mathrm{Fe}_{2} \mathrm{O}_{3}$ and $\mathrm{MnO}$ at unit III (Figure 5) further supports the abundant micronodules and Fe-oxyhydroxides from the third layer.

\section{Geochemical and mineralogical investigations of isolated polymetallic sulfide grains from CR sed- iment}

The stereographic microscopic observation, SEM, and EDS investigations of Wocan-1 and Wocan-2 stations (Table 3) revealed that the hydrothermal sulfide components separated from the metalliferous sediments of Carlsberg Ridge were mainly composed of pyrite, chalcopyrite, sphalerite and secondary Cu-sulfide minerals (Figure 6).

Table 2: Average values of Micro-chemical (EPMA) composition of micro modules separated from Carlsberg Ridge sediments.

\begin{tabular}{|l|l|l|l|l|l|l|}
\hline & Fe & Mn & Co & Ni & Cu \\
\hline 1 & 30.32 & 19.46 & 0.24 & 0.33 & 0.19 \\
\hline 2 & 18.47 & 23.86 & 0.12 & 0.19 & 0.15 \\
\hline 3 & 16.86 & 24.64 & 0.21 & 0.22 & 0.16 \\
\hline 4 & 22.84 & 22.33 & 0.21 & 0.17 & 0.18 & 0.18 \\
\hline Average & 19.39 & 22.14 & 0.19 & 0.22 & 0.17 \\
\hline
\end{tabular}

All values are in wt\%. Source

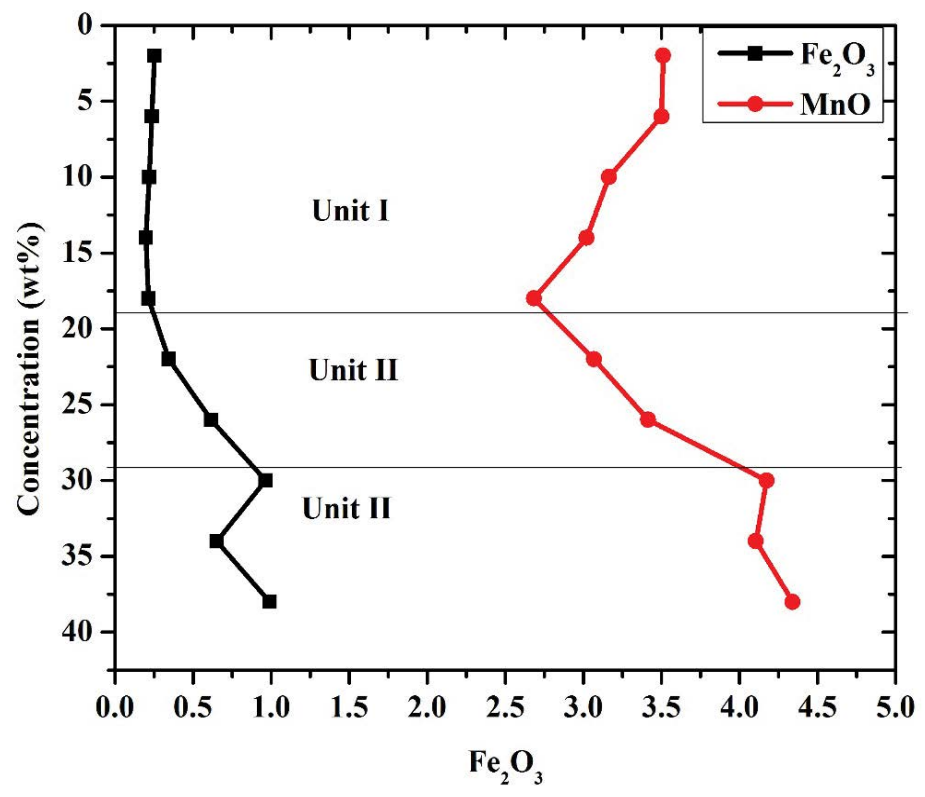

Figure 5: The Fe-Mn concentration of the sediment core samples recovered off Wocan and Tianxiu vent field. 
Citation: Popoola SO, Akintoye AE (2021) Integrated Geochemical Investigations on Fe-Mn Nodules, Polymetallic Sulfides and Fe-Mn Oxides Recovered from Marine Sediments of Carlsberg Ridge, Northwest Indian Ocean. Adv Environ Stud 5(1):394-403

Table 3: Average values of Micro-chemical (EPMA) compositions of Chalcopyrite (Cpy), pyrite (py) and sphalerite (sph) recovered from CR sediment.

\begin{tabular}{|l|l|l|l|l|l|l|l|}
\hline & S & Fe & As & Se & Cu & Co & Zn \\
\hline Cpy & 35.43 & 30.33 & Bld & 0.02 & 34.46 & 0.03 & Bld \\
\hline Py & 53.15 & 46.36 & 0.11 & 0.03 & 0.08 & 0.05 & 0.01 \\
\hline Sph & 33.685 & 2.26 & Bld & Bld & 0.065 & Bld & 63.18 \\
\hline & Sb & Ag & Pb & Au & Cd & Mo & Total \\
\hline Cpy & 0.02 & 0.01 & 0.08 & Bld & Bld & Bld & 100.38 \\
\hline Py & 0.01 & 0.01 & 0.15 & 0.01 & Bld & Bld & 99.97 \\
\hline Sph & Bld & Bld & 0.04 & Bld & 0.375 & 0.025 & 99.63 \\
\hline
\end{tabular}

All values are in wt\%
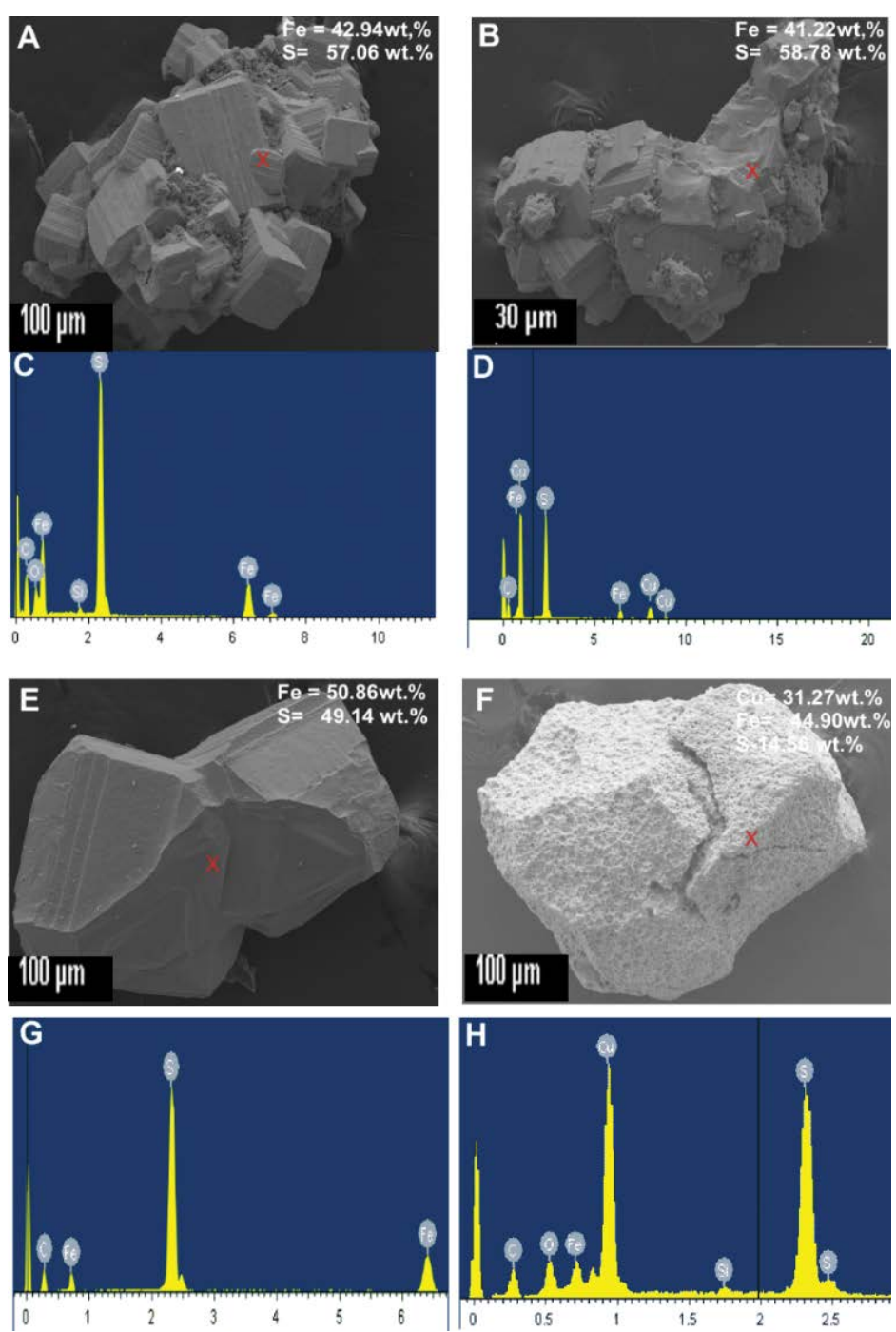

Figure 6: SEM morphology and EDS spectrum and values (wt. \%) of representative sulfide mineral grains from the Carlsberg Ridge, NW Indian Ocean. The $\mathrm{X}$ spot indicates the analysed spot. A-B are representative pyrite grains, C-D is the respective spectrum. E-F are representative pyrite and chalcopyrite grains $\mathrm{G}-\mathrm{H}$ are the respective spectrum.

The sulfides from the active (Wocan-1) stations showed euhedral texture. The mineral chemistry further revealed $\mathrm{Cu}$ and Co enrichment of up to 0.08 and 0.05 wt\% (Table 3).

\section{Geochemical and mineralogical investigations of} isolated Fe-Mn oxide grains from C.R sediment

XRD investigations revealed goethite in association with 
Citation: Popoola SO, Akintoye AE (2021) Integrated Geochemical Investigations on Fe-Mn Nodules, Polymetallic Sulfides and Fe-Mn Oxides Recovered from Marine Sediments of Carlsberg Ridge, Northwest Indian Ocean. Adv Environ Stud 5(1):394-403

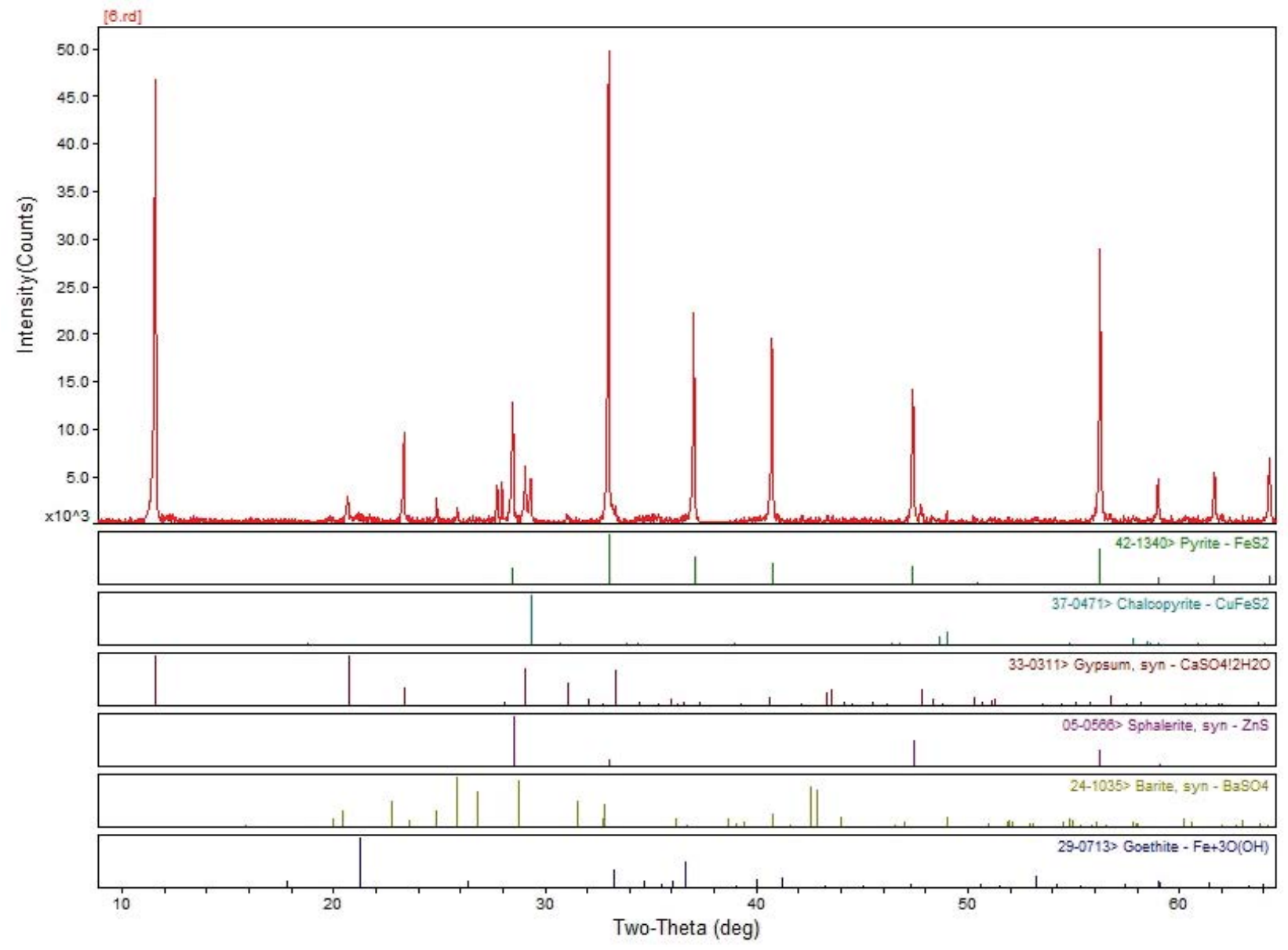

Figure 7: XRD patterns of the bulk sediment from Carlsberg Ridge.

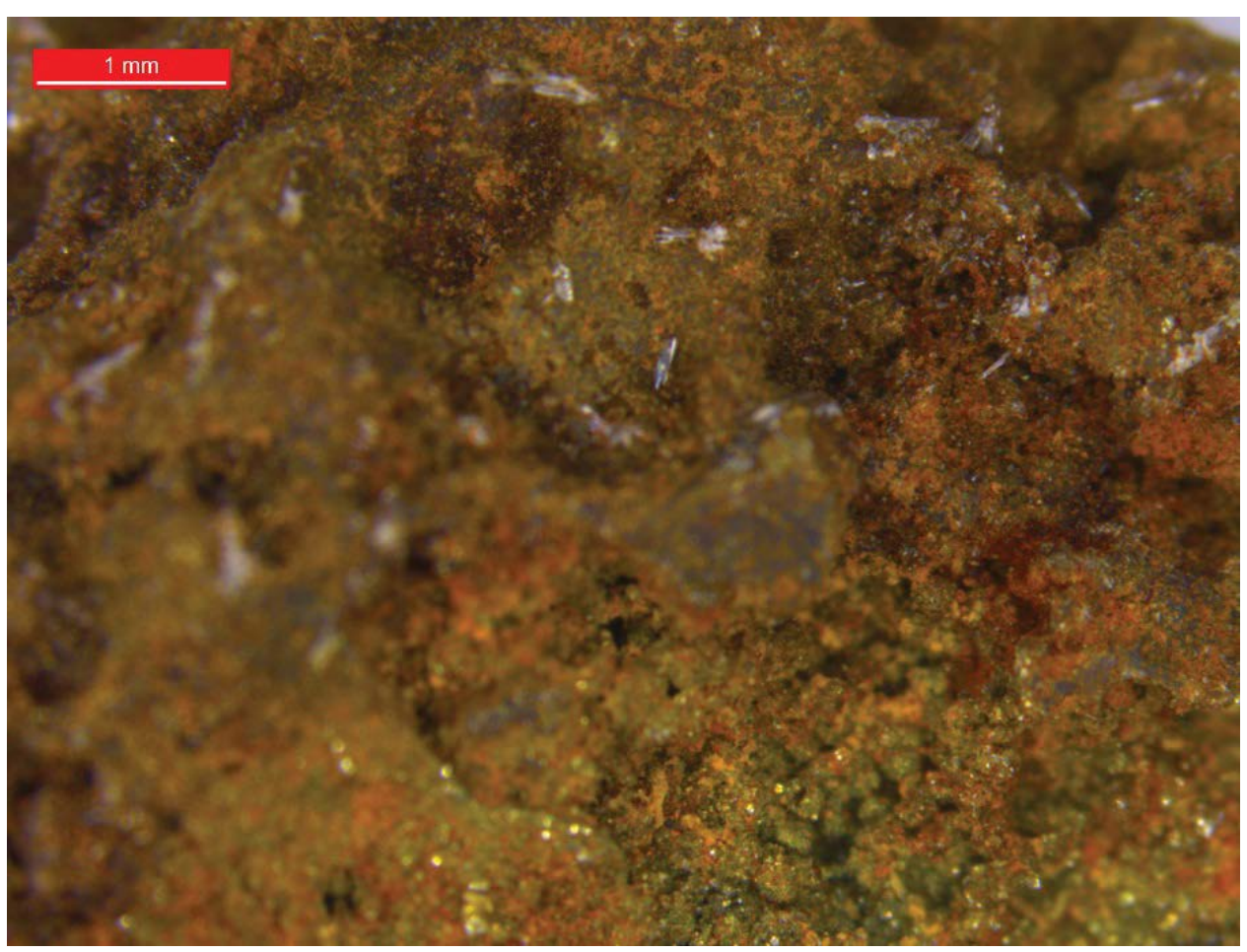

Figure 8: Photomicrographs of separated grains of Fe-Mn Oxide grains separated from the sediments of Carlsberg Ridge. 
Citation: Popoola SO, Akintoye AE (2021) Integrated Geochemical Investigations on Fe-Mn Nodules, Polymetallic Sulfides and Fe-Mn Oxides Recovered from Marine Sediments of Carlsberg Ridge, Northwest Indian Ocean. Adv Environ Stud 5(1):394-403

sulphide and sulphate minerals (Figure 7 and Figure 8). The mineral chemistry (EPMA) of the isolated Fe-Mn oxides further reveal $\mathrm{Ni}, \mathrm{Cu}$, as and $\mathrm{Zn}$ of up to $0.04 \mathrm{wt} \%, 0.60 \mathrm{wt} \%, 0.06$ wt\% and 0.51 wt\% respectively (Table 4$)$.

\section{Discussions}

\section{The research gap}

Recent studies on CR were concentrated on the mineralogy and geochemistry of hydrothermal precipitates and metalliferous sediments $[5,6,25]$. The studies confirmed the occurrence of seafloor weathering and mixing of hydrothermal fluid with seawater (during the waning stages of hydrothermal process) as the controlling factor in sulphur isotopic concentrations, minor and trace element re-distributions. Ref [29] suggested Cu-Zn-Fe sulphides as the dominant minerals in the proximal sediments of the Tianxiu hydrothermal field $(0-0.22 \mathrm{~km})$. While fine-grained Fe-oxides and hydroxides and calcite minerals dominated the distal sediments (1.84$6.05 \mathrm{~km}$ ). This is an indication of particle size characteristics as a factor of a hydrothermal indicator. Ref [31] worked on 3 sediment push cores collected via submersible jiaolong to determine the degree of evolution of hydrothermal activity in the WHF. They further conducted Pb-Sr isotopes on the push core samples. They confirmed that the Wocan-1 site exhibit a pervasive hydrothermal activity that spans 1069 years, with Fe fluxes of $9483-10834 \mathrm{mg} \mathrm{cm}-2 \mathrm{kyr}-1$, while the Wocan-2 site had been inactive since $4864 \pm 114$-years before present ( $y r$ BP). Ref [32] worked on the Fe and S isotope fractionation and suggest a $\delta^{56} \mathrm{Fe}$ ranges of $-2.05 \%$ o- $0.10 \%$. The $\delta^{34} \mathrm{~S}$ concentrations of the Wocan-1 and Wocan-2 sediments fall within the range reported by [6]. Ref [30] worked on the Daxi vent field (an active mafic hosted hydrothermal systems at a non-transform offset) in the CR and suggested the occurrence of a silica-rich chimney, and sulfide chimney dominated by sphalerite, pyrrhotite (with enriched $\mathrm{Sn}, \mathrm{Co}$ and $\mathrm{Ag}$ ).

The right direction in the CR's studies is the identification of seven mega fauna species (including allvellid worms) in the Daxi vent field. However, there is a dearth of information on the lifestyles, adaptation and trophic requirements of endemic/chemosynthetic vent fauna in Wocan vent field; Tianxiu vent field; Daxi vent field and other recently discovered hydrothermal fields in the Indian Ocean. This call for thorough research into the endemic/chemosynthetic vent fauna of the recently discovered vent field in the Central Indian Ridge (MESO, [33]; Kairei, [34]; Edmond, [35]; Dodo and Solitaire [36]; Yokoniwa [37]. A similar approach is required in Longqi-1, Longqi-2 (49 39' $\mathrm{E}$; [38,39]; Yuhuang $49^{\circ} 16^{\prime} \mathrm{E}$, [40]; Xilongjing $49^{\circ} 40^{\prime} \mathrm{E}$, and Zhanqiao $50^{\circ} 59^{\prime} \mathrm{E}$ [41]; Duanqiao $50^{\circ}$
24'E, [42] and Mount Jourdanne [43] along the South West Indian Ridge (SWIR).

At present, the public and private institutions have rediscovered the zeal in deep-sea mining exploration and exploitation. However, further research on the relationships between Nodules, Sulfides and Fe-Mn crusts with marine sediments and marine ecosystems requires an interdisciplinary approach and collaboration among marine geologists, marine geophysicists, marine geochemists, scientists, macro/microbiologists, marine biogeochemists, environmental management, social scientists, engineers, contractors/investors, legal scholars, and economists.

\section{Conclusions}

The geochemical and mineralogical investigation of proximal and distal sediments from Wocan hydrothermal sites, $\mathrm{CR}$, Indian Ocean revealed diverse marine mineral deposits (Fe-Mn nodules, polymetallic sulfides and Fe-Mn crust). The recovered micro-nodules at $\sim 300 \mathrm{~km}$ to the $\mathrm{CR}$ ridge segment ranges from botryoidal to spherical, with $\mathrm{Mn}$ concentration of up to $44.63 \mathrm{wt} \%$, and Fe vales of up to $26.95 \mathrm{wt} \%$. The EPMA investigations revealed average $\mathrm{Cu}, \mathrm{Co}, \mathrm{Ni}, \mathrm{Zn}$ concentrations of 0.17 wt $\%, 0.19 w t \%, 0.23$ wt\%, and 0.15 wt $\%$. The hydrothermal sulfide components separated from the metalliferous sediments of Carlsberg Ridge were mainly composed of pyrite, chalcopyrite, sphalerite and secondary Cu-sulfide minerals. The sulfides of the Wocan-1 stations showed more euhedral texture, with $\mathrm{Cu}$ and $\mathrm{Co}$ enrichment of up to 0.08 and 0.05 wt\%. The recovered Fe-Mn oxides are angular to sub-angular, yellowish to reddish-brown with goethite minerals, and $\mathrm{Ni}, \mathrm{Cu}, \mathrm{As}$ and $\mathrm{Zn}$ concentrations of up to $0.04 \mathrm{wt} \%, 0.60 \mathrm{wt} \%$, 0.06 wt\% and 0.51 wt\%.

This study suggests a combination of science and policy (e.g., micro/macro biologists, ecologists, marine geoscientists, contractors, environmental managers, civil society, ecotoxicologists) on the marine mineral deposits of Carlsberg Ridge for a thorough understanding of the species, dynamics, structure, distributions, lifestyles and adaptation, trophic requirements and reproductive characteristics of the associated sediment faunas from the effect of anthropogenic disturbance arising from deep-sea mining of these mineral deposits from $C R$ and other vent fields along the Indian Ocean.

\section{Acknowledgements}

The support of Han's research group, the second Institute of oceanography and marine research, and the Zhejiang University, Hangzhou China during this study is highly appreciated. The captains and crew of R/V Zhukezhen (DY $28^{\text {th }}$ cruise) for their immense support during the investigations and

Table 4: Electron probe microanalysis results (wt\%) for Fe-Mn oxides from Carlsberg Ridge.

\begin{tabular}{|c|c|c|c|c|c|c|c|c|c|c|c|}
\hline Element & $\mathrm{SiO}_{2}$ & $\mathrm{SO}_{3}$ & $\mathrm{FeO}$ & $\mathrm{MnO}$ & $\mathrm{TiO}_{2}$ & $\mathrm{Al}_{2} \mathrm{O}_{3}$ & $\mathrm{Al} / \mathrm{Al}+\mathrm{Fe}+\mathrm{Mn}$ & $\mathrm{Fe} / \mathrm{Mn}$ & & & \\
\hline \multirow[t]{2}{*}{ Av } & 11.82 & 0.10 & 67.5 & 0.06 & 0.06 & 0.31 & 0.003 & 2,486 & & & \\
\hline & $\mathrm{Cu}$ & Co & $\mathbf{N i}$ & $\mathrm{Ba}$ & Sr & As & $\mathrm{Zn}$ & $\mathrm{Pb}$ & Total & $\begin{array}{l}\mathrm{H}_{2} \mathrm{O}^{+} \\
\text {(calc) }\end{array}$ & $\begin{array}{c}\mathrm{Cu}+\mathrm{Co}+\mathrm{Zn} \\
+\mathrm{Ni}\end{array}$ \\
\hline $\mathrm{Av}$ & 0.66 & $\mathrm{Bdl}$ & 0.04 & 0.04 & 0.02 & 0.06 & 0.51 & 0.10 & 81.7 & 18.28 & 1.19 \\
\hline
\end{tabular}

Av: Average, $n=11$. 
Citation: Popoola SO, Akintoye AE (2021) Integrated Geochemical Investigations on Fe-Mn Nodules, Polymetallic Sulfides and Fe-Mn Oxides Recovered from Marine Sediments of Carlsberg Ridge, Northwest Indian Ocean. Adv Environ Stud 5(1):394-403

sampling of the Wocan Hydrothermal Field, Carlsberg Ridge, Northwest Indian Ocean, and the four anonymous reviewers for the helpful comments that have greatly improved the manuscript.

\section{References}

1. Somozza L, Gonzalez FJ (2019) Special issue "Marine geology and minerals".

2. Dekov MV, Marchig V, Rajta I, et al. (2003) Fe-Mn micro nodules born in the metalliferous sediments of two spreading centres: The East Pacific Rise and Mid-Atlantic Ridge. Marine Geology 199: 101-121.

3. Varentsov IM, Drits VA, Gorshkov Al, et al. (1991) Mn-Fe oxyhydroxide crusts from Krylov Seamount (Eastern Atlantic): Mineralogy, geochemistry and genesis. Marine Geology 96: 53-70.

4. Wang X, Zeng Z, Qi H, et al. (2014) Fe-Si-Mn-oxyhydroxide encrustations on basalts at East Pacific Rise near 13N: An SEM-EDS study. Journal of Ocean University of China 13: 917-925.

5. Popoola S, Han X, Wang Y, et al. (2019) Geochemical investigations on Fe-Si-Mn oxyhydroxides deposits in Wocan hydrothermal field on the slow-spreading Carlsberg Ridge, Indian Ocean: Constraints on their types and origin. Minerals 9: 19.

6. Popoola S, Han X, Wang Y, et al. (2019) Mineralogical and geochemical signatures of metalliferous sediments in Wocan-1 and Wocan-2 hydrothermal sites on the Carlsberg Ridge, Indian Ocean. Minerals 9: 26.

7. Dymond J, Corliss JB, Heath GR, et al. (1973) Origin of metalliferous sediments from the Pacific Ocean. Geological Society of America Bulletin 84: 3355-3372.

8. German CR, Higgs NC, Thomson J, et al. (1993) A geochemical study of metalliferous sediment from the TAG hydrothermal mound, $26^{\circ} 08^{\prime} \mathrm{N}$, Mid-Atlantic Ridge. Journal of Geophysical Research: Solid Earth 98: 9683-9692.

9. Parson LM, Patriat P, Searle RC, et al. (1993) Segmentation of the Central Indian Ridge between $12^{\circ} 12^{\prime} S$ and the Indian Ocean Triple Junction. Marine Geophysical Research 15: 265-282.

10. Drolia RK, Iyer SD, Chakraborty B, et al. (2003) The Northern Central Indian Ridge: Geology and tectonics of fracture zones-dominated spreading ridge segments. Current Science 85: 290-298.

11. Kamesh RKA (2008) Recent cruise onboard R/V Sonne to the Carlsberg Ridge and the Andaman Sea. InterRidge News 17: 34-35.

12. McKenzie DP, Sclater JG (1971) The evolution of the Indian Ocean since the late Cretaceous. Geophysical Journal of the Royal Astronomical Society 25: 437-528.

13. Royer JY, Sandwell DT (1989) Evolution of the eastern Indian ocean since the late cretaceous: Constraints from geosat altimetry. Journal of Geophysical Research: Solid Earth 94: 1375513782.

14. Christie DM, West BP, Pyle DG, et al. (1998) Chaotic topography, mantle flow and mantle migration in the Australian-Antarctic discordance. Nature 394: 637-644.

15. Mahoney JJ, Graham DW, Christie DM, et al. (2002) Between a hotspot and a coldspot: Isotopic variation in the southeast Indian Ridge asthenosphere, $86^{\circ} \mathrm{E}-118^{\circ} \mathrm{E}$. Journal of Petrology 43 : 1155-1176.

16. Murton BJ, Tindle AG, Milton JA, et al. (2005) Heterogeneity in southern Central Indian Ridge MORB: Implications for ridge- hotspot interaction. Geochemistry Geophysics Geosystems 6.

17. Nauret F, Abouchami W, Galer SJG, et al. (2006) Correlated trace element- $\mathrm{Pb}$ isotope enrichments in Indian MORB along $18-20^{\circ} \mathrm{S}$, Central Indian Ridge. Earth and Planetary Science Letters 245: 137-152.

18. Ray D, lyer SD, Banerjee R, et al. (2007) Petrology and Geochemistry of basalts from the Northern Central Indian Ridge $\left(3-11^{\circ} \mathrm{S}\right)$ : Implications for the evolution of MORB. Acta Geological Sinica 81: 99-112.

19. Ray D, Misra S, Banerjee R, et al. (2011) Geochemical implications of gabbro from slow-spreading Northern Central Indian Ocean Ridge, Indian Ocean. Geological Magazine 148: 404-422.

20. Chaubey AK, Bhattacharya GC, Murthy GPS, et al. (1993) Spreading history of the Arabian sea: Some new constraints. Marine Geology 112: 343-352.

21. Kamesh RKA, Kodagali VN, Fujimoto H (1998) Three-dimensional gravity and magnetic studies over a segment of the Carlsberg ridge. In: $35^{\text {th }}$ Annual Convention and Meeting on Continental Margins of India-Evolution, Processes, and Potentials, Indian Geophysical Union, NIO, Goa, 29.

22. Mudholkar AV, Kodagali VN, Kamesh RKA, et al. (2002) Geomorphological and petrological observations along a segment of slow-spreading Carlsberg Ridge. Curr Sci 8: 982-989.

23. Murton BJ, Rona PA (2015) Carlsberg Ridge and Mid-Atlantic Ridge: Comparison of slow spreading centreanalogues. Deep Sea Research Part II: Topical Studies in Oceanography 121: 71-84.

24. Han (2015) First ultramafic-hosted hydrothermal sulfide deposit discovered on the Carlsberg Ridge, Northwest Indian Ocean. Third InterRidge Theoretical Institute titled "Magmatic and Tectonic Processes and Sea bed Resources at Mid Ocean Ridges, Hangzhou, China.

25. Wang Y, Han X, Petersen S, et al. (2017) Mineralogy and trace element geochemistry of sulfide minerals from the Wocan hydrothermal field on the slow-spreading Carlsberg Ridge, Indian Ocean. Ore Geology Reviews 84: 1-19.

26. Popoola SO, Unyimadu JP, Adegbie AT, et al. (2019) Hydrothermal components in marine sediments: An insight into sea floor mineralization process. Academic Journal of Chemistry 4: 27-33.

27. Han X, Popoola S, Qiu Z, et al. (2019) Extreme hydrothermal activity on Carlsberg Ridge during the last glacial stage: Evidence from an off-axis sediment core. Inter Ridge Workshop on Hydrothermal Ore-forming Processes, 22-27.

28. Wang Y (2019) The daxi vent field on the slow-spreading Carlsberg Ridge: An active hydrothermal system at a non-transform offset. Inter Ridge Workshop on Hydrothermal Ore-forming Processes 22-27.

29. Cai Y, Han X, Qiu Z, et al. (2020) Characteristics, distribution and implication of hydrothermal minerals in Tianxiu hydrothermal field, Carlsberg Ridge, Northwest Indian Ocean. Marine Geology \& Quaternary Geology.

30. Yejian W, Xiqiu H, Yadong Z, et al. (2021) The daxi vent field: An active mafic-hosted hydrothermal system at a non-transform offset on the slow-spreading Carlsberg Ridge, $6^{\circ} 48^{\prime} \mathrm{N}$, Ore Geology Reviews 129: 103888.

31. Zhongyan Q, Xiqiu H, Mou L, et al. (2021) The temporal variability of hydrothermal activity of Wocan hydrothermal field, Carlsberg Ridge, Northwest Indian Ocean. Ore Geology Reviews 132: 103999. 
Citation: Popoola SO, Akintoye AE (2021) Integrated Geochemical Investigations on Fe-Mn Nodules, Polymetallic Sulfides and Fe-Mn Oxides Recovered from Marine Sediments of Carlsberg Ridge, Northwest Indian Ocean. Adv Environ Stud 5(1):394-403

32. Shujie W, Weidong S, Jing $H$, et al. (2021) Iron and sulfur isotopes of sulfides from the Wocan hydrothermal field, on the Carlsberg Ridge, Indian Ocean. Ore Geology Reviews.

33. Halbach P, Blum N, Münch U, et al. (1998) Formation and decay of a modern massive sulfide deposit in the Indian Ocean. Mineralium Deposita 33: 302-309.

34. Gamo T, Chiba H, Yamanaka T, et al. (2001) Chemical characteristics of newly discovered black smoker fluids and associated hydrothermal plumes at the Rodriguez triple junction, Central Indian Ridge. Earth and Planetary Science Letters 193: 371-379.

35. Van DCL, Humphris SE, Fornari D, et al. (2001) Biogeography and ecological setting of Indian Ocean hydrothermal vents. Science 294: 818-823.

36. Nakamura K, Watanabe H, Miyazaki J, et al. (2012) Discovery of new hydrothermal activity and chemosynthetic fauna on the Central Indian Ridge at $18^{\circ}-20^{\circ}$ S. PLoS ONE 7: e32965.

37. Fujii M, Okino K, Sato T, et al. (2016) Origin of magnetic highs at ultramafic hosted hydrothermal systems: Insights from the Yokoniwa site of Central Indian Ridge. Earth and Planetary Science Letters 441: 26-37.
38. Tao C, Li H, Huang W, et al. (2011) Mineralogical and geochemical features of sulfide chimneys from the $49^{\circ} 39^{\prime} \mathrm{E}$ hydrothermal field on the Southwest Indian Ridge and their geological inferences. Chin Sci Bull 56: 2828-2838.

39. Tao C, Lin J, Guo S, et al. (2012) DY115-19 (Legs 1-2) and DY11520 (Legs 4-7) science parties, first active hydrothermal vents on an ultraslow-spreading center: Southwest Indian Ridge. Geology 40: 47-50.

40. Han X, Wu G, Cui R, et al. (2010) Discovery of a hydrothermal sulfide deposit on the Southwest Indian Ridge at $49.2^{\circ} \mathrm{E}$. American Geophysical Union, Fall Meeting.

41. China Ocean Mineral Resources R\&D Association (COMRA) (2016) Chinese gazetteer of undersea features on the international seabed. China Ocean Press, Beijing.

42. Tao C, Li H, Jin X, et al. (2014) Seafloor hydrothermal activity and polymetallic sulfide exploration on the Southwest Indian Ridge. Chin Sci Bull 59: 2266-2276.

43. Münch U, Blum N, Halbach P (1999) Mineralogical and geochemical features of sulfide chimneys from the MESO zone, Central Indian Ridge. Chem Geol 155: 29-44. 